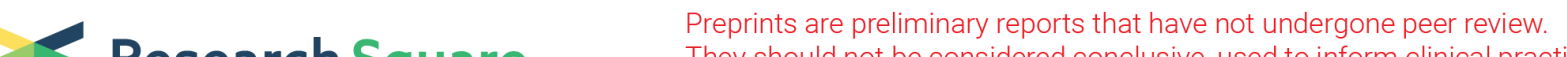 $\begin{array}{ll}\text { Research Square } & \text { They should not be considered conclusive, used to inform clinical practice, } \\ \text { or referenced by the media as validated information. }\end{array}$
}

\section{An Assessment of the Psychosocial Evaluation for Early Liver Transplantation in Patients with Acute Alcoholic Hepatitis in the context of Alcohol Use Disorder, A Case Control Study}

\section{Aryeh Dienstag ( $\square$ aryehd@hadassah.org.il)}

Department of Psychiatry, Hadassah Hebrew University School of Medicine, Jerusalem

\section{Penina Dienstag}

Department of Anesthesia, Hadassah Hebrew University School of Medicine, Jerusalem

Kanwal Mohan

Mount Sinai Hospital

Omar Mirza

Mount Sinai Hospital

Elizabeth Schubert

Mount Sinai Hospital

Laura Ford

Mount Sinai Hospital

Margot Edelman

Mount Sinai Hospital

Gene Im

Mount Sinai Hospital

Akhil Shenoy

Columbia University Medical Center

\section{Research Article}

Keywords: Alcoholism, alcohol use disorder, Psychosomatic Medicine, alcoholic liver disease, acute alcoholic hepatitis, predict alcohol relapse, traditional psychosocial selection criteria

Posted Date: September 30th, 2021

DOl: https://doi.org/10.21203/rs.3.rs-799319/v1

License: (9) This work is licensed under a Creative Commons Attribution 4.0 International License. Read Full License 


\section{Abstract \\ Background}

Severe acute alcoholic hepatitis (AAH) has an excessive mortality rate. As a result, many centers, including our own, have allowed transplant listing patients for transplantation prior to achievement of 6months sobriety. Concurrently, scoring systems have been proposed to identify patients with alcohol use disorder (AUD) predisposed to relapse after liver transplantation. These scoring systems target patients with a minimal period of sobriety.

\section{Methods}

We conducted a retrospective case control study of 11 patients who underwent early liver transplantation for AAH matched with 11 controls who were declined secondary to low insight into AUD. Blinded raters confirmed the severity of the DSM- 5 diagnosis and scored the patients on a variety of structured psychometric scales used to predict alcohol relapse. These included the High Risk for Alcohol Relapse scale (HRAR), Stanford Integrated Psychosocial Assessment Tool (SIPAT), Alcohol Relapse Risk Assessment (ARRA), Hopkins Psychosocial Scale (HPSS), Michigan Alcoholism Prognosis Score (MAPS), Alcohol Use Disorders Identification Test -Consumption (AUDIT-C) and Sustained Alcohol Use Post-Liver Transplant (SALT) scales. All patients who underwent transplantation were followed for harmful and nonharmful drinking until the end of the study period.

\section{Results}

Mean psychometric scores of the transplanted cases were significantly different than the controls. Cases chosen for transplant had significantly favorable MAPS, HRAR, SIPAT, ARRA, and HPSS scores with cutoffs matching their prior research. The SALT and AUDIT-C scores were not predictive of our selection of patients for transplant. Despite expedited assessment and no significant period of sobriety, our case cohort had a $30 \%$ relapse to harmful drinking after an average of 6.6 years ( 5 to 8.5 years) of follow-up.

\section{Discussion}

Despite the expedited assessment and short to no period of sobriety, the patient cohort demonstrated a $30 \%$ relapse to harmful drinking, consistent with the reported $20-30 \%$ after liver transplantation for all forms of alcoholic liver disease. The average MAPS, HRAR, SIPAT, ARRA, and HPSS scores all corroborated our current stratification procedures, with lower risk mean scores found in the transplanted group.

\section{Conclusion}


The traditional psychosocial selection criteria for patients with alcoholic hepatitis at our institution is consistent with four of the five investigated scoring systems.

\section{Introduction}

Risk factors associated with alcohol relapse after liver transplantation have been extensively studied (14) Length of sobriety is considered a significant protective factor in sustained abstinence. Historically, patients who require liver transplantation for alcohol-associated liver disease (ALD) been asked to complete six months of sobriety prior to being considered for liver transplantation.(5) However, patients suffering from severe Acute alcoholic hepatitis (AAH) not responding to medical therapy have a mortality rate of over $70 \%$ by six months(6) making the six month sobriety rule a virtual death sentence for most of these patients. In highly selected patients, early liver transplantation for AAH has been shown to achieve excellent clinical outcomes with a low impact on the donor pool (7-9). We previously studied mortality in a case control study of patients selected for transplant after a first episode of AAH (9) applying the selection criteria as originally outlined by Mathurin et al(7). The psychosocial team sought candidates with a first liver decompensating event, new insight into alcohol use disorder (AUD), motivation for sobriety and strong social support. Special emphasis was placed on having good insight in the face of new liver disease as a practical way to measure readiness for transplant. These basic criteria have become standard protocol in further studies of patients presenting with AAH. $(10,11)$ No scoring system was used in evaluating the candidates.

In one of the largest cohorts of SAH, comprising 12 transplant centers and 147 patients, the primary reason not to list was psychosocial (73\%) with the remaining reasons, medical contraindications (12\%), clinical improvement during evaluation (8\%) and financial/insurance (7\%).(12) In attempt to predict alcohol relapse after LT for those with alcohol use disorder (AUD) and ALD multiple scoring systems have both been created (13) and attempted validation(14),

Commonly used scales to assess patients with AAH for appropriateness for liver transplant include, the High Risk for Alcohol Relapse scale (HRAR), Alcohol Relapse Risk Assessment (ARRA), Hopkins Psychosocial Scoring System (HPSS), Sustained Alcohol use post-LT (SALT), Stanford Integrated Psychosocial Assessment Tool (SIPAT), Michigan Alcoholism Prognosis Scale (MAPS) and the Alcohol Use Disorder Identification Test - Concise (AUDIT-C) $(5,15,16)$. Table 1 summarizes the factors and scoring assessed by the respective assessment scales. 
Table 1

Overview and scoring of the respective assessment tools

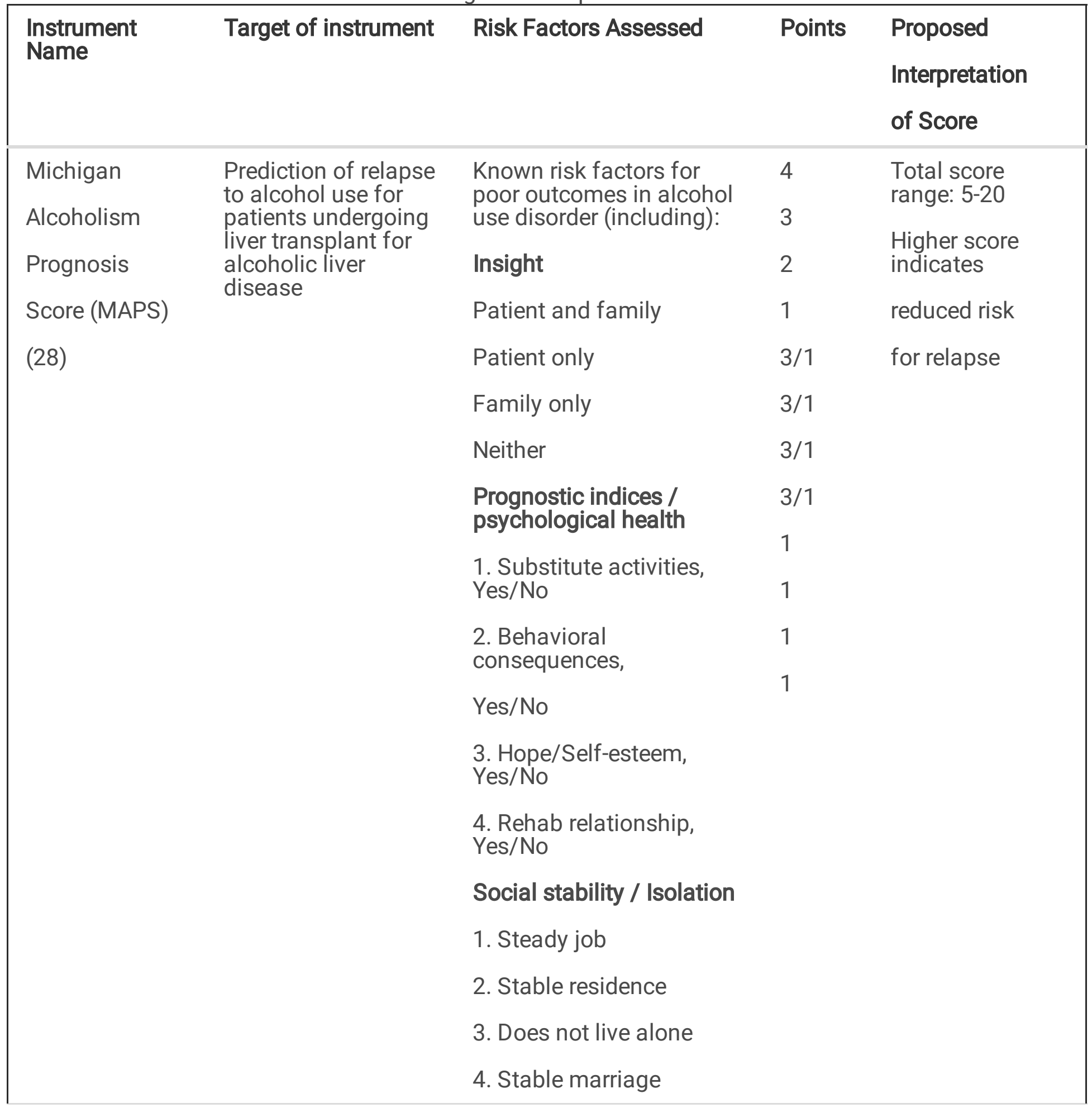

Modified from Shenoy 2021(15), Im 2019 (5) and Lim 2018 (13) 


\begin{tabular}{|c|c|c|c|c|}
\hline $\begin{array}{l}\text { Instrument } \\
\text { Name }\end{array}$ & Target of instrument & Risk Factors Assessed & Points & $\begin{array}{l}\text { Proposed } \\
\text { Interpretation } \\
\text { of Score }\end{array}$ \\
\hline $\begin{array}{l}\text { High-Risk } \\
\text { Alcoholism } \\
\text { Relapse Scale } \\
\text { (HRAR) } \\
(24)\end{array}$ & $\begin{array}{l}\text { Prediction of relapse } \\
\text { and time to relapse } \\
\text { for patients } \\
\text { suffering from } \\
\text { alcohol use disorder } \\
\text { Not specific for } \\
\text { organ transplant }\end{array}$ & $\begin{array}{l}\text { Known risk factor for } \\
\text { relapse in alcohol use } \\
\text { disorder (including): } \\
\text { Duration of heavy drinking } \\
\text { (years) } \\
<1111-25>25 \\
\text { Usual number of daily } \\
\text { drinks } \\
<99-17>17 \\
\text { Number of prior } \\
\text { alcoholism inpatient } \\
\text { treatment } \\
\text { experiences } \\
01>1\end{array}$ & $\begin{array}{l}012 \\
012 \\
012\end{array}$ & $\begin{array}{l}\text { Total score } \\
\text { range: } 0-6 \\
<4=\text { Low } \\
\text { alcoholism } \\
\text { risk } \\
\geq 4=\text { High } \\
\text { alcoholism risk }\end{array}$ \\
\hline
\end{tabular}

Modified from Shenoy 2021(15), Im 2019 (5) and Lim 2018 (13) 


\begin{tabular}{|c|c|c|c|c|}
\hline $\begin{array}{l}\text { Instrument } \\
\text { Name }\end{array}$ & Target of instrument & Risk Factors Assessed & Points & $\begin{array}{l}\text { Proposed } \\
\text { Interpretation } \\
\text { of Score }\end{array}$ \\
\hline $\begin{array}{l}\text { Alcohol Use } \\
\text { Disorders } \\
\text { Identification } \\
\text { Test - } \\
\text { Consumption } \\
\text { (AUDIT-C) } \\
\text { (29) }\end{array}$ & $\begin{array}{l}\text { Screening test to } \\
\text { identify patients } \\
\text { who are hazardous } \\
\text { drinkers or have } \\
\text { active alcohol use } \\
\text { disorders based on } \\
\text { previously validated } \\
\text { tools used to screen } \\
\text { for problematic } \\
\text { alcohol use. } \\
\text { Not specific for } \\
\text { organ transplant or } \\
\text { patients who had } \\
\text { reduced or } \\
\text { attempted to reduce } \\
\text { alcohol } \\
\text { consumption }\end{array}$ & $\begin{array}{l}\text { Questions specifically } \\
\text { relevant to present heavy } \\
\text { alcohol consumption } \\
\text { How often did you have a } \\
\text { drink containing alcohol in } \\
\text { the past year? } \\
\text { Never } \\
\text { Monthly or less } \\
\text { Two to four times a } \\
\text { month } \\
\text { Two to three times a week } \\
\text { Four or more times a week } \\
\text { How many drinks did you } \\
\text { have on a typical day } \\
\text { when you were drinking in } \\
\text { the past year? } \\
\text { None, I do not drink } \\
1 \text { or } 2 \\
3 \text { or } 4 \\
5 \text { or } 6 \\
7 \text { to } 9 \\
10 \text { or more } \\
\text { How often did you have } \\
\text { six or more drinks on one } \\
\text { occasion in the past year? } \\
\text { Never } \\
\text { Less than monthly } \\
\text { Monthly } \\
\text { Weekly } \\
\text { Daily or almost daily } \\
\text { (n) }\end{array}$ & $\begin{array}{l}1 \\
2 \\
3 \\
4 \\
0 \\
1 \\
2 \\
3 \\
4\end{array}$ & $\begin{array}{l}\text { Total score } \\
\text { range: 0-12 } \\
\text { Low Risk: 0- } \\
3 \text { points } \\
\text { Moderate Risk: 4- } \\
5 \text { points } \\
\text { High Risk: 6- } \\
7 \text { points } \\
\text { Severe Risk: 8- } \\
12 \text { points }\end{array}$ \\
\hline Stanford & Comprehensive & Patient's readiness level & $0-4$ & Total score \\
\hline
\end{tabular}




\begin{tabular}{|c|c|c|c|c|}
\hline $\begin{array}{l}\text { Instrument } \\
\text { Name }\end{array}$ & Target of instrument & Risk Factors Assessed & Points & $\begin{array}{l}\text { Proposed } \\
\text { Interpretation } \\
\text { of Score }\end{array}$ \\
\hline $\begin{array}{l}\text { Integrated } \\
\text { Psychosocial } \\
\text { Assessment for } \\
\text { Transplantation } \\
\text { (SIPAT) } \\
\text { (30) }\end{array}$ & $\begin{array}{l}\text { psychosocial } \\
\text { assessment used to } \\
\text { predict psychosocial } \\
\text { outcomes in } \\
\text { patients undergoing } \\
\text { solid organ } \\
\text { transplant } \\
\text { Not specific for } \\
\text { alcohol use disorder }\end{array}$ & $\begin{array}{l}\text { and } \\
\text { illness management } \\
\text { 1. } \\
\text { Knowledge/understanding } \\
\text { of the } \\
\text { medical illness } \\
\text { 2. } \\
\text { Knowledge/understanding } \\
\text { of } \\
\text { transplantation } \\
\text { 3. Willingness/desire for } \\
\text { treatment (transplant) } \\
\text { 4. History of treatment } \\
\text { adherence/compliance } \\
\text { 5. Lifestyle factors } \\
\text { Social support system } \\
\text { level of } \\
\text { readiness } \\
\text { 6. Availability of social } \\
\text { support system } \\
\text { 7. Functionality of social } \\
\text { support } \\
\text { system } \\
\text { 8. Appropriateness of } \\
\text { living space and } \\
\text { environment } \\
\text { Psychological stability } \\
\text { and } \\
\text { psychopathology } \\
\text { 9. Psychopathology }\end{array}$ & $\begin{array}{l}0-4 \\
0-4 \\
0-8 \\
0-4 \\
0-8 \\
0-8 \\
0-4 \\
0-14 \\
0-7 \\
0-4 \\
0-8 \\
0-4 \\
0-8 \\
0-4 \\
0-8 \\
0-4 \\
0-5\end{array}$ & $\begin{array}{l}\text { range: } 0-110 \\
\cdot 0-6 \\
\text { Excellent } \\
\text { candidate } \\
\cdot 7-20 \\
\text { Good candidate } \\
\cdot 21-39 \\
\text { Minimally } \\
\text { Acceptable } \\
\text { Candidate } \\
\cdot 40-68 \\
\text { High Risk } \\
\text { candidate } \\
\cdot>69 \\
\text { Poor Candidate }\end{array}$ \\
\hline
\end{tabular}




\begin{tabular}{|c|c|c|c|c|}
\hline $\begin{array}{l}\text { Instrument } \\
\text { Name }\end{array}$ & Target of instrument & Risk Factors Assessed & Points & $\begin{array}{l}\text { Proposed } \\
\text { Interpretation } \\
\text { of Score }\end{array}$ \\
\hline & & $\begin{array}{l}\text { 10. History of } \\
\text { neurocognitive }\end{array}$ & & \\
\hline & & impairment & & \\
\hline & & $\begin{array}{l}\text { 11. Influence of } \\
\text { personality traits }\end{array}$ & & \\
\hline & & versus disorder & & \\
\hline & & $\begin{array}{l}\text { 12. Effect of truthfulness } \\
\text { versus }\end{array}$ & & \\
\hline & & deceptive behavior & & \\
\hline & & $\begin{array}{l}\text { 13. Overall risk for } \\
\text { psychopathology }\end{array}$ & & \\
\hline & & $\begin{array}{l}\text { Lifestyle and effect of } \\
\text { substance }\end{array}$ & & \\
\hline & & use & & \\
\hline & & $\begin{array}{l}\text { 14. Alcohol use, abuse, } \\
\text { and }\end{array}$ & & \\
\hline & & dependence & & \\
\hline & & $\begin{array}{l}\text { 15. Alcohol abuse: risk for } \\
\text { recidivism }\end{array}$ & & \\
\hline & & $\begin{array}{l}\text { 16. Substance } \\
\text { use/abuse/dependence }\end{array}$ & & \\
\hline & & $\begin{array}{l}\text { 17. Substance } \\
\text { use/abuse/dependence: }\end{array}$ & & \\
\hline & & risk for recidivism & & \\
\hline & & $\begin{array}{l}\text { 18. Nicotine } \\
\text { use/abuse/dependence }\end{array}$ & & \\
\hline
\end{tabular}

Modified from Shenoy 2021(15), Im 2019 (5) and Lim 2018 (13) 


\begin{tabular}{|c|c|c|c|c|}
\hline $\begin{array}{l}\text { Instrument } \\
\text { Name }\end{array}$ & Target of instrument & Risk Factors Assessed & Points & $\begin{array}{l}\text { Proposed } \\
\text { Interpretation } \\
\text { of Score }\end{array}$ \\
\hline $\begin{array}{l}\text { Alcohol } \\
\text { Relapse Risk } \\
\text { Assessment } \\
\text { (ARRA) } \\
\text { (31) }\end{array}$ & $\begin{array}{l}\text { Prediction of relapse } \\
\text { to alcohol use in } \\
\text { patients suffering } \\
\text { from alcohol use } \\
\text { disorder undergoing } \\
\text { orthotopic liver } \\
\text { transplant }\end{array}$ & $\begin{array}{l}\text { Known risk factors for } \\
\text { alcohol relapse in } \\
\text { liver disease } \\
\text { 1. Absence of HCC } \\
\text { 2. Tobacco dependence } \\
\text { 3. Alcohol use after liver } \\
\text { disease } \\
\text { diagnosis } \\
\text { 4. Low motivation for } \\
\text { alcohol } \\
\text { treatment } \\
\text { 5. Poor stress } \\
\text { management skills } \\
\text { 6. No rehabilitation } \\
\text { relationship } \\
\text { 7. Limited social support } \\
\text { 8. Lack of nonmedical } \\
\text { behavioral } \\
\text { consequences } \\
\text { in Continued engagement } \\
\text { in social } \\
\text { present }\end{array}$ & $\begin{array}{l}\text { One } \\
\text { point } \\
\text { for } \\
\text { every } \\
\text { factor } \\
\text { present }\end{array}$ & $\begin{array}{l}\text { Total score } \\
\text { range: 0-9 } \\
0 \text { points: } \\
\text { minimal risk } \\
\text { 1-3 points: mild } \\
\text { risk } \\
\text { 4-6 points: } \\
\text { moderate risk } \\
\text { 7-9 points: } \\
\text { severe risk }\end{array}$ \\
\hline
\end{tabular}

Modified from Shenoy 2021(15), Im 2019 (5) and Lim 2018 (13) 


\begin{tabular}{|c|c|c|c|c|}
\hline $\begin{array}{l}\text { Instrument } \\
\text { Name }\end{array}$ & Target of instrument & Risk Factors Assessed & Points & $\begin{array}{l}\text { Proposed } \\
\text { Interpretation } \\
\text { of Score }\end{array}$ \\
\hline \multirow{15}{*}{$\begin{array}{l}\text { Hopkins } \\
\text { Psychosocial } \\
\text { Scale (HPSS) } \\
\text { (8) }\end{array}$} & \multirow{15}{*}{$\begin{array}{l}\text { Prediction of alcohol } \\
\text { relapse for patients } \\
\text { undergoing LT for } \\
\text { severe alcohol } \\
\text { associated hepatitis. } \\
\text { Utilizing unique } \\
\text { factors specific for } \\
\text { patients with severe } \\
\text { alcoholic hepatitis in } \\
\text { addition to Known } \\
\text { risk factors for } \\
\text { relapse in AUD. }\end{array}$} & Protective Characteristics & $0-2$ & $\begin{array}{l}\text { Total score } \\
\text { range: }-12-10\end{array}$ \\
\hline & & $\begin{array}{l}\text { 1. Self-admission to } \\
\text { hospital }\end{array}$ & $0-2$ & High-risk HPSS \\
\hline & & & $0-2$ & score $\leq 0$ \\
\hline & & $\begin{array}{l}\text { 2. Urinks/day pre- } \\
\text { abstinence }\end{array}$ & $0-2$ & \multirow{12}{*}{$\begin{array}{l}\text { Low-risk HPSS } \\
\text { score }>0\end{array}$} \\
\hline & & 3. Insight into diagnosis & $0-2$ & \\
\hline & & 4. Marital status & $-2-0$ & \\
\hline & & $\begin{array}{l}\text { 5. Abstinence before } \\
\text { transplant }\end{array}$ & $-2-0$ & \\
\hline & & At Risk Characteristics & & \\
\hline & & 1. Psychiatric comorbidity & $-2-0$ & \\
\hline & & $\begin{array}{l}\text { 2. History of other } \\
\text { substance abuse }\end{array}$ & $-2-0$ & \\
\hline & & $\begin{array}{l}\text { 3. History of failed rehab } \\
\text { attempt }\end{array}$ & & \\
\hline & & $\begin{array}{l}\text { 4. Family history of } \\
\text { alcoholism }\end{array}$ & & \\
\hline & & $\begin{array}{l}\text { 5. Employment just prior } \\
\text { to }\end{array}$ & & \\
\hline & & presentation & & \\
\hline & & $\begin{array}{l}\text { 6. Legal History related to } \\
\text { alcohol }\end{array}$ & & \\
\hline
\end{tabular}

Modified from Shenoy 2021(15), Im 2019 (5) and Lim 2018 (13) 


\begin{tabular}{|c|c|c|c|c|}
\hline $\begin{array}{l}\text { Instrument } \\
\text { Name }\end{array}$ & Target of instrument & Risk Factors Assessed & Points & $\begin{array}{l}\text { Proposed } \\
\text { Interpretation } \\
\text { of Score }\end{array}$ \\
\hline $\begin{array}{l}\text { Sustained } \\
\text { Alcohol Use } \\
\text { Post-Liver } \\
\text { Transplant } \\
\text { (SALT) } \\
\text { (18) }\end{array}$ & $\begin{array}{l}\text { Prediction of brief } \\
\text { relapse ("slip") and } \\
\text { sustained relapse to } \\
\text { alcohol use in } \\
\text { patients undergoing } \\
\text { early liver transplant } \\
\text { for severe alcohol } \\
\text { associated hepatitis }\end{array}$ & $\begin{array}{l}\text { Simplified psychosocial } \\
\text { assessment of known risk } \\
\text { factors specific for } \\
\text { patients with severe } \\
\text { alcoholic } \\
\text { hepatitis } \\
\text { 1. }>10 \text { drinks/day at } \\
\text { presentation } \\
\text { 2. } \geq 2 \text { prior failed } \\
\text { rehabilitation attempts } \\
\text { 3. Any history of prior } \\
\text { alcohol-related } \\
\text { legal issues } \\
\text { 4. Hx of non-THC illicit } \\
\text { substance abuse }\end{array}$ & $\begin{array}{l}+4 \\
+4 \\
+2 \\
+1\end{array}$ & $\begin{array}{l}\text { Higher the score } \\
\text { the greater risk } \\
\text { for relapse } \\
\text { (no specific a } \\
\text { priori cut off) }\end{array}$ \\
\hline
\end{tabular}

We wished to understand how these scoring systems could have been used as a selection tool in our patient population as well as what factors, as defined by the assessment tools, significantly characterized our candidates in comparison to patients not listed for transplant as well as patients' posttransplant outcomes. We hypothesize that the psychometric properties of these scales will validate our process of selecting patients based on either good or developing insight into their alcohol misuse.

\section{Methods}

This study was a retrospective case-control using the first 11 cases that were psychosocially cleared with expedited listing and underwent early liver transplantation for alcoholic hepatitis at the Recanati-Miller Transplantation Institute at Mount Sinai Hospital. The psychosocial team evaluated 81 inpatients with SAH and less than 3 months of sobriety for LT between 1/2012-6/2015 and psychosocially cleared 22 $(27 \%)$. Both psychiatry and social work independently evaluated all potential candidates with this presentation in the hospital. 11 were transplanted after additional medical and surgical clearance. In addition to the patient interview, the level of addiction was corroborated with family and friends. The control group ( $n=11)$ were age, sex, and year-matched patients from the cohort who were also assessed as inpatients but declined for psychosocial reasons $(n=59)$. Two psychosomatic fellows (AD and KM) retrospectively reviewed the psychiatric and social work data confirming the DSM- 5 diagnosis of AUD and scored the HRAR, ARRA, HPSS, and SIPAT. The raters were blinded to the evaluation decision and 
transplant outcomes. The MAPS, AUDIT-C and SALT were scored by one of the authors (AS) who had originally evaluated all the patients. The scores of the psychosocially accepted cases and declined controls were compared using two tailed t-tests with $95 \%$ confidence intervals. Sensitivity and specificity for the cut-off points used for these scoring systems was calculated. Means from the cases and controls are compared to patient populations in the reviewed literature. Follow up data of all patients who underwent transplantation for SAH have been collected for harmful drinking over a minimum of 3 years. All patients were seen every 2 weeks in the first 3 months after transplant, monthly for the next 6 months, and every 3-6 months depending on stability in the first 3 years. Regular post-transplant interviews, routine, and random urine ethyl glucuronide (UETG) testing, social work involvement, and corroboration from family and outpatient providers helped in relapse assessment. IRB approval was obtained for a chart review of all patients evaluated for early LT at the Mount Sinai Hospital.

\section{Results}

Of the 81 patients evaluated by the psychosocial team for alcoholic hepatitis, 11 (14\%) were psychosocially cleared and transplanted. All the cases $(n=11)$ and controls $(n=11)$ met criteria for AUD and had similar lengths of sobriety prior to evaluation (mean 35 vs 22 days, $p=.08$ ). Transplanted cases vs. controls tended to present with their first liver decompensation ( $73 \%$ vs. $27 \%)$ and with good or developing insight ( $91 \%$ vs. $27 \%$ ). Both groups had similar levels of acceptable social support ( $100 \%$ vs. 73\%). Three cases presented with their second liver decompensation and were transplanted due to overwhelming support from the recipient review committee. One case with poor insight was similarly cleared and transplanted. The number of drinks per day, years of drinking, failed rehab history and family history were not different between the groups. (Table 2) 
Table 2

Characteristics of Cases and Controls with Scoring Systems

\begin{tabular}{|llll|}
\hline & $\begin{array}{l}\text { Transplanted } \\
(\mathbf{n = 1 1 )}\end{array}$ & $\begin{array}{l}\text { Controls } \\
(\mathbf{n}=11)\end{array}$ & $\mathbf{p}$ \\
\hline Age (years) & 43.8 & 45 & 0.4 \\
\hline Sex (female) & $55 \%$ & $55 \%$ & 1.0 \\
\hline Number of drinks per day & 9.9 & 14.7 & 0.17 \\
\hline Years of alcohol use & 20.9 & 28.5 & 0.20 \\
\hline Hx of failed rehab & $27 \%$ & $36 \%$ & 0.66 \\
\hline Family Hx of Alcoholism & $27 \%$ & $45 \%$ & 0.37 \\
\hline Alcohol Use Disorder Diagnosis & $100 \%$ & $100 \%$ & 1.0 \\
\hline Severe & $6 / 11$ & $11 / 11$ & \\
\hline Moderate & $3 / 11$ & $0 / 11$ & \\
\hline Mild & $2 / 11$ & $0 / 11$ & \\
\hline Sober time prior to evaluation (days) & 35 & 22 & 0.08 \\
\hline First liver decompensation & $73 \%$ & $27 \%$ & 0.03 \\
\hline Good or developing insight & $91 \%$ & $27 \%$ & 0.002 \\
\hline Consistent report with collateral & $91 \%$ & $45 \%$ & .053 \\
\hline Good social support & $100 \%$ & $73 \%$ & 0.06 \\
\hline
\end{tabular}

The MAPS, HRAR, SIPAT, ARRA, and HPSS all discriminated the cases from the controls. The mean case score was a higher MAPS $(m=17.1)$, lower HRAR $(m=2.0)$, lower SIPAT $(m=23.5)$, lower ARRA $(m=2.3)$, and higher HPSS $(m=2.4)$. The following scores helped classify cases from controls in the expected direction: MAPS 14, HRAR 3, SIPAT 40, ARRA 4, and HPSS 0. The AUDIT-C and SALT scores were not significant different between the groups. (Table 3). 
Table 3

Scoring System results

\begin{tabular}{|llllll|}
\hline Scoring Systems (score range) & Mean & $\mathbf{( 9 5 \%} \mathrm{Cl})$ & Mean & $\mathbf{( 9 5 \% ~ C l )}$ & \\
\hline MAPS $(5-20)$ & 17.09 & $(15.41,18.77)$ & 10.00 & $(8.15,11.85)$ & $<0.001$ \\
\hline HRAR $(0-6)$ & 2.09 & $(1.68,2.50)$ & 3.09 & $(2.37,3.81)$ & 0.03 \\
\hline AUDIT-C $(0-12)$ & 9.09 & $(7.09,11.09)$ & 11.27 & $(10.21,12.33)$ & 0.08 \\
\hline SIPAT $(0-110)$ & 23.27 & $(16.50,30.04)$ & 49.45 & $(45.46,53.44)$ & $<0.001$ \\
ARRA $(0-9)$ & 2.27 & $(1.74,2.80)$ & 5.70 & $(4.99,6.41)$ & 0.01 \\
HPSS $(-14-10)$ & 3.27 & $(0.85,5.69)$ & -2.20 & $(-4.48,-0.08)$ & 0.005 \\
\hline SALT $(0-12)$ & 3.82 & $(2.09,5.55)$ & 5.00 & $(3.37,6.63)$ & 0.34 \\
\hline
\end{tabular}

A heat map was created to illustrate the wide range of scores color coded for concerning risk for relapse (Figure 1). No single cut-off score on any of the tools would have selected the transplanted patients in this cohort nor declined the patients in the control. The mode of the AUDIT-C was 12 (the max score).

One transplanted patient died in the first 6 months from post-surgical complications. The surviving transplanted cohort $(n=10)$ had positive psychosocial characteristics with low HRAR $(m=2.0)$, low ARRA $(m=2.3)$, high HPSS $(m=2.4)$, low SALT $(m=3.8)$, and low SIPAT $(m=23.5)$. The cohort has been followed from 5 to 8.5 years (mean $=6.6$ years). Three patients $(\# 4, \# 5$ and \#11) relapsed to regular alcohol use with one dying of liver failure (Figure 1: Heat Map).

\section{Discussion}

In prospective studies of risk factors for relapse in liver transplant patients, a diagnosis of alcohol dependence (severe or moderate AUD), a family history of alcoholism, low social support, and a shorter duration of pre-transplant sobriety predicted relapse (4). However, in cases of severe AAH in which there is limited time to either wait for a lengthier period of sobriety period or refer to AUD treatment, a new paradigm must be sought. Our transplant cohort, like the control group, had a high burden of alcohol use, addictive behavior, and genetic loading - as demonstrated by the high AUDIT-C score in both groups.

Outpatient compliance with addiction treatment was not possible as many of these patients were too sick for discharge. Despite this, the primary criteria of selecting patients with new decompensated liver failure, good insight into their addiction, and strong social support helped identify a successful cohort with a $20 \%$ relapse rate after a mean of five years follow-up (9) and a 30\% relapse rate after a mean of 6.6 years follow-up. This relapse rate is consistent with the reported $20-30 \%$ relapse to heavy drinking after liver transplantation for all forms of alcoholic liver disease.(17) We cannot comment on the potential relapse outcomes of the patients who were not transplanted and did not survive. 
Validated cut-off scores(15) of the HRAR $<3$, ARRA $<4$, HPSS $>0$, and SIPAT $<40$ would have corroborated the stratification process used in our center. However, given the recent findings from the large multi-center that SALT scores below 5 had a 95\% NPV for sustained alcohol use post LT(18), it is possible that our psychosocial clearance was too strict and 5 out of the 11 controls would have been deemed acceptable candidates by this score alone.

The MAPS and HRAR scoring systems highly correlated with our institutional psychosocial assessment, potentially because its emphasis on insight into AUD as a potential protective factor (19) paralleled our use of emerging insight in the face of new liver disease. The utilization of new insight has been a practical way to measure readiness for transplant. This finding is consistent with prior studies that have identified self-awareness of choice behavior (insight) as a prediction of substance disorder related choices in addiction (20). Similarly, the SIPAT and HPSS, with their focus on readiness for transplant and social support $(8,21)$ were correlated with our institutional assessment. This is comparable to prior research which identifies social support as a protective factor against relapse to alcohol use disorder (22, 23). Interestingly, there was a statistical difference in the HRAR scores between the two groups even though it is composed of elements (24), which are also risk factors for AAH (6).

As the medical community has moved to see alcohol use disorder as an illness, and not a vice, it has become universally accepted that patients with ALD should not be automatically excluded from receiving a liver transplant $(25,26)$. However, assessment of patients with ALD has been criticized as somewhat subjective and inconsistent (27). The use numeric scoring systems partially alleviates the ethical predicament by introducing a numeric score that can be used consistently to portray a patient's alcohol related behaviors; akin to the way the MELD score is used to depict the severity of a patient's liver dysfunction. In our case the objective scales for the most part reflected the risk stratification that our institution had used in our initial AAH transplant population.

Limitations of the case-control include the retrospective nature of our data collection was, and our the small sample size of patients cleared and transplanted. The small sample size was largely a function of the high mortality associated with severe AAH and that only $27 \%$ of all potential transplant candidates evaluated psychosocially were deemed acceptable by the method used at our center. This clearance rate was similar to the Franco-Belgian study done by Mathurin et al (7) using similar criteria for clearance. Larger cohorts which include a wide range of risk scores will be necessary to validate the use of any one of these tools as well as to analyze which individual factors can prognosticate a favorable candidate in this unique population.

\section{Conclusions}

Patients with AUD and new insight into their addiction, social support, and readiness for transplant at the time of their evaluation for transplantation have low rates of alcohol relapse after transplantation.

Scoring systems may approximate and objectify this traditional selection process. These scoring systems may have varied utility in their helping Patients with ALD should instead be evaluated in an 
attempt to stratify risk for selection for transplantation, and should be referred for AUD treatment, and post-LT follow up. Centers that are performing liver transplants for patients with alcoholic hepatitis should include a psychosocial team with addiction expertise and consider known risk factors for AUD relapse in their initial assessments.

\section{List Of Abbreviations}

AAH Acute alcoholic hepatitis

AUD Alcohol Use Disorder

ALD Alcohol-Associated Liver Disease

DSM-5 Diagnostic and Statistical Manual of Mental Disorders, $5^{\text {th }}$ edition

MAPS Michigan Alcohol Prognosis Scale

HRAR High Risk Alcohol Relapse Scale

AUDIT-C Alcohol Use Disorder Identification Test - Concise

SIPAT Stanford Integrated Psychosocial Assessment Tool

ARRA Alcohol Relapse Risk Assessment

HPSS Hopkins Psychosocial Scoring System

SALT Sustained Alcohol use post-LT

SAH severe alcohol-related hepatitis

HCC hepatocellular carcinoma

uETG urine ethyl glucuronide

IRB Internal Review Board

\section{Declarations}

\section{Ethics approval and consent to participate}

All experimental protocols were approved by the Mount Sinai Hospital Institutional Review Board.

IRB approval was obtained for a chart review of all patients evaluated for early LT at the Mount Sinai Hospital by the Mount Sinai Hospital internal review board, the Program for the Protection of Human Subjects (PPHS) at Mount Sinai. 
Obtaining informed consent to participate in the study was not applicable in this case as the study was a retrospective chart review. Informed consent was waived by the Program for the Protection of Human Subjects (PPHS) at Mount Sinai.

All methods were carried out in accordance with relevant guidelines and regulations.

\section{Consent for publication}

Informed consent was waived by the Program for the Protection of Human Subjects (PPHS) at Mount Sinai. As no identifying information is to be published

\section{Availability of data and materials}

All data generated or analyzed during this study are included in this published article

\section{Competing interests}

The authors declare that they have no competing interests

\section{Funding}

This study received no outside sources of funding

\section{Authors' contributions}

$A D$ was involved in preparing the manuscript, as well as retrospectively reviewing the psychiatric and social work data confirming the DSM- 5 diagnosis of AUD and scored the HRAR, ARRA, HPSS, and SIPAT.

PD was involved in preparing the manuscript

$\mathrm{KM}$ was involved in retrospectively reviewing the psychiatric and social work data confirming the DSM-5 diagnosis of AUD and scored the HRAR, ARRA, HPSS, and SIPAT psychometric scales

OM was involved in preparing the manuscript

ES performed the initial pre-transplant psychosocial evaluation

LF performed the initial pre-transplant psychosocial evaluation

ME performed the initial pre-transplant psychosocial evaluation

GI performed the pre- and post-transplant medical evaluations

AS was involved in editing the manuscript, performed the initial pre-transplant psychiatric evaluations and retrospectively scored the MAPS, AUDIT-C and SALT psychometric scales

\section{Acknowledgements}


Not applicable

\section{Authors' information (optional)}

Aryeh Dienstag - Is an attending psychiatrist at the Hadassah Medical Center in Jerusalem

Penina Dienstag - Is an attending anesthesiologist at the Hadassah Medical Center in Jerusalem

Kanwal Mohan - Clinical Assistant Professor of psychiatry, University of Calgary

Omar Mirza - Director of Cosultation-Liaison Psychiatry at Harlem Hospital at NYC Health + Hospitals

Elizabeth Schubert - Is a social worker at the Recanati-Miller Transplantation Institute, Mount Sinai Hospital

Laura Ford - Is a social worker at the Recanati-Miller Transplantation Institute, Mount Sinai Hospital

Margot Edelman - Is a social worker at the Recanati-Miller Transplantation Institute, Mount Sinai Hospital

Gene Im - Is an attending nephrologist at the Recanati-Miller Transplantation Institute, Mount Sinai Hospital

Akhil Shenoy - Is an attending psychiatrist at the Columbia University Medical Center

\section{References}

1. Dew MA, Dimartini AF, Steel J, De A, Dabbs V, Myaskovsky L, et al. Meta-Analysis of Risk for Relapse to Substance Use After Transplantation of the Liver or Other Solid Organs. Liver Transpl [Internet]. 2008;14:159-72. Available from: www.interscience.wiley.com

2. Rice JP, Lucey MR. Should length of sobriety be a major determinant in liver transplant selection? Curr Opin Organ Transplant [Internet]. 2013 Jun;18(3):259-64. Available from: http://journals.Iww.com/00075200-201306000-00003

3. Rustad JK, Stern TA, Prabhakar M, Musselman D. Risk Factors for Alcohol Relapse Following Orthotopic Liver Transplantation: A Systematic Review. Psychosomatics [Internet]. 2015;56(1):2135. Available from: http://dx.doi.org/10.1016/j.psym.2014.09.006

4. Dimartini A, Dew MA, Day N, Fitzgerald MG, Jones BL, Devera ME, et al. Trajectories of Alcohol Consumption Following Liver Transplantation. Am J Transplant [Internet]. 2010;10:2305-12. Available from: http://www.andrew.cmu.edu/user/bjones

5. Im GY, Cameron AM, Lucey MR. Liver transplantation for alcoholic hepatitis. J Hepatol [Internet]. 2019;70(2):328-34. Available from: https://doi.org/10.1016/j.jhep.2018.11.007

6. Hosseini N, Shor J, Szabo G. Alcoholic Hepatitis: A Review. Alcohol Alcohol. 2019;54(4):408-16. 
7. Mathurin P, Moreno C, Samuel D, Dumortier J, Salleron J, Durand F, et al. Early Liver Transplantation for Severe Alcoholic Hepatitis. N Engl J Med [Internet]. 2011 Nov 10 [cited 2021 Jul 2];365(19):1790800. Available from: http://link.springer.com/10.1007/s10620-020-06159-9

8. Lee BP, Chen PH, Haugen C, Hernaez R, Gurakar A, Philosophe B, et al. Three-year results of a pilot program in early liver transplantation for severe alcoholic hepatitis. Ann Surg. 2017;265(1):20-9.

9. Im GY, Kim-Schluger L, Shenoy A, Schubert E, Goel A, Friedman SL, et al. Early Liver Transplantation for Severe Alcoholic Hepatitis in the United States - A Single-Center Experience. Am J Transplant. 2016;16(3):841-9.

10. Weeks SR, Sun Z, McCaul ME, Zhu H, Anders RA, Philosophe B, et al. Liver Transplantation for Severe Alcoholic Hepatitis, Updated Lessons from the World's Largest Series. J Am Coll Surg [Internet]. 2018;226(4):549-57. Available from: https://doi.org/10.1016/j.jamcollsurg.2017.12.044

11. Sundaram V, Wu T, Klein AS, Noureddin M, Kim IK, Todo T, et al. Liver Transplantation for Severe Alcoholic Hepatitis: Report of a Single Center Pilot Program. Transplant Proc. 2018;50(10):3527-32.

12. Lee BP, Mehta N, Platt L, Gurakar A, Rice JP, Lucey MR, et al. Outcomes of Early Liver Transplantation for Patients With Severe Alcoholic Hepatitis. Gastroenterology [Internet]. 2018;155(2):422-430.e1. Available from: https://doi.org/10.1053/j.gastro.2018.04.009

13. Lim J, Sundaram V. Risk factors, scoring systems, and interventions for alcohol relapse after liver transplantation for alcoholic liver disease. Clin Liver Dis [Internet]. 2018 May;11(5):105-10. Available from: https://onlinelibrary.wiley.com/doi/10.1002/cld.696

14. Deutsch-Link S, Weinrieb RM, Jones LS, Solga SF, Weinberg EM, Serper M. Prior Relapse, Ongoing Alcohol Consumption, and Failure to Engage in Treatment Predict Alcohol Relapse After Liver Transplantation. Vol. 65, Digestive Diseases and Sciences. 2020. p. 2089-103.

15. Shenoy A, Dienstag A, Dienstag P, Ford L, Schubert E, Wankoff M, et al. Scoring systems to assess relapse risk in alcohol use disorder presenting for early liver transplantation: A systematic review. Gen Hosp Psychiatry [Internet]. 2021 Sep;72:23-30. Available from: https://linkinghub.elsevier.com/retrieve/pii/S0163834321000979

16. Lim J, Curry MP, Sundaram V. Risk factors and outcomes associated with alcohol relapse after liver transplantation. World J Hepatol. 2017;9(17):771-80.

17. Kim JS, Kim GJ, Lee JM, Lee CS, Oh JK. HAIS (Hanil Alcohol Insight Scale): validation of an insightevaluation instrument for practical use in alcoholism. J Stud Alcohol [Internet]. 1998 Jan;59(1):52-5. Available from: http://www.jsad.com/doi/10.15288/jsa.1998.59.52

18. Lee BP, Vittinghoff E, Hsu C, Han H, Therapondos G, Fix OK, et al. Predicting Low Risk for Sustained Alcohol Use After Early Liver Transplant for Acute Alcoholic Hepatitis: The Sustained Alcohol Use Post-Liver Transplant Score. Hepatology. 2019;69(4):1477-87.

19. Beresford TP, Turcotte JG, Merion R, Burtch G, Blow FC, Campbell D, et al. A Rational Approach to Liver Transplantation for the Alcoholic Patient. Psychosomatics [Internet]. 1990 Aug 1 [cited 2021 Jul 13];31(3):241-54. Available from: https://linkinghub.elsevier.com/retrieve/pii/S0033318290721603 
20. Moeller SJ, Hajcak G, Parvaz MA, Dunning JP, Volkow ND, Goldstein RZ. Psychophysiological prediction of choice: relevance to insight and drug addiction. Brain [Internet]. 2012 Nov;135(11):3481-94. Available from: https://academic.oup.com/brain/article/135/11/3481/271975

21. Maldonado JR, Sher Y, Lolak S, Swendsen H, Skibola D, Neri E, et al. The Stanford Integrated Psychosocial Assessment for Transplantation: A Prospective Study of Medical and Psychosocial Outcomes. Vol. 77, Psychosomatic Medicine. 2015. p. 1018-30.

22. Havassy BE, Hall SM, Wasserman DA. Social support and relapse: Commonalities among alcoholics, opiate users, and cigarette smokers. Addict Behav. 1991;16(5):235-46.

23. Moon T-J, Mathias CW, Mullen J, Karns-Wright TE, Hill-Kapturczak N, Roache JD, et al. The Role of Social Support in Motivating Reductions in Alcohol Use: A Test of Three Models of Social Support in Alcohol-Impaired Drivers. Alcohol Clin Exp Res [Internet]. 2019 Jan;43(1):123-34. Available from: https://onlinelibrary.wiley.com/doi/10.1111/acer.13911

24. Yates WR, Booth BM, Reed DA, Brown K, Masterson BJ. Descriptive and predictive validity of a highrisk alcoholism relapse model. J Stud Alcohol. 1993;54(6):645-51.

25. Marroni CA, De Medeiros Fleck A, Fernandes SA, Galant LH, Mucenic M, De Mattos Meine MH, et al. Liver transplantation and alcoholic liver disease: History, controversies, and considerations. World $\mathrm{J}$ Gastroenterol. 2018 Jul 14;24(26):2785-805.

26. Mellinger JL, Volk ML. Transplantation for Alcohol-related Liver Disease: Is It Fair? Alcohol Alcohol [Internet]. 2018;53(2):173-7. Available from: https://academic.oup.com/alcalc/article/53/2/173/4721792

27. Solga SF, Serper M, Young RA, Forde KA. Transplantation for Alcoholic Hepatitis: Are We Achieving Justice and Utility? Spec Artic | Hepatol. 2019;69(4).

28. Beresford TP, Schwartz J, Wilson D, Merion R, Lucey MR. The Short-Term Psychological Health of Alcoholic and Non-Alcoholic Liver Transplant Recipients. Alcohol Clin Exp Res [Internet]. 1992 Oct;16(5):996-1000. Available from: https://onlinelibrary.wiley.com/doi/10.1111/j.15300277.1992.tb01908.x

29. Bradley KA, McDonell MB, Bush K, Kivlahan DR, Diehr P, Fihn SD. The AUDIT Alcohol Consumption Questions. Alcohol Clin Exp Res [Internet]. 1998 Nov;22(8):1842. Available from: http://doi.wiley.com/10.1097/00000374-199811000-00034

30. Maldonado JR, Dubois HC, David EE, Sher Y, Lolak S, Dyal J, et al. The Stanford Integrated Psychosocial Assessment for Transplantation (SIPAT): A New Tool for the Psychosocial Evaluation of Pre-Transplant Candidates. Psychosomatics [Internet]. 2012 Mar;53(2):123-32. Available from: https://linkinghub.elsevier.com/retrieve/pii/S0033318211003938

31. Rodrigue J, Hanto D, Curry M. The alcohol relapse risk assessment: A scoring system to predict the risk of relapse to any alcohol use after liver transplant. Prog Transplant. 2013;23(4):310-8.

\section{Figures}




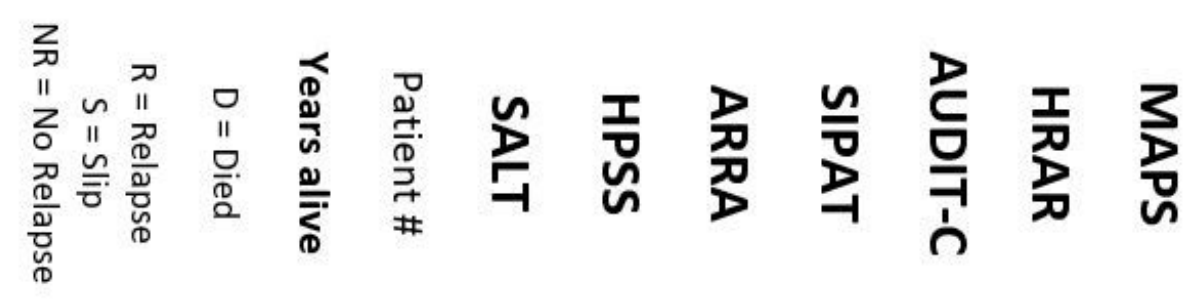

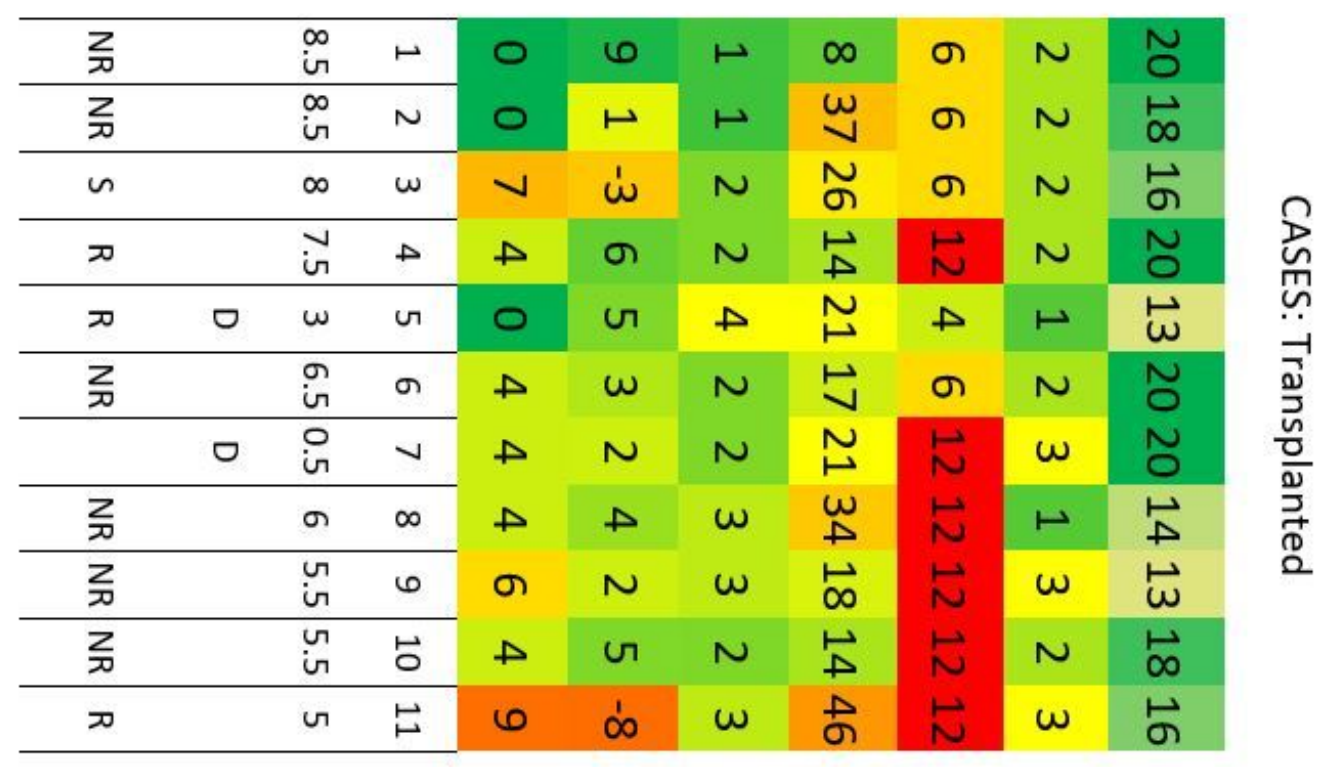

\begin{tabular}{|c|c|c|c|c|c|c|}
\hline v & '̀ & v & के & $\mapsto$ & $\mapsto$ & $\stackrel{\omega}{\omega}$ \\
\hline$\mapsto$ & ن́ & $V$ & $\overrightarrow{6}$ & の & $\mapsto$ & \\
\hline$\triangle$ & $N$ & G & U & $\vec{\sim}$ & $\omega$ & 㲾 \\
\hline U & á & $\sigma$ & जึ & $\stackrel{\sim}{\sim}$ & $\omega$ & $\mapsto$ \\
\hline v & $\dot{\omega}$ & G & $\underset{\infty}{\omega}$ & 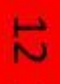 & $\Delta$ & • \\
\hline ص & $\infty$ & $\sigma$ & v & 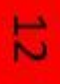 & V & $\infty$ \\
\hline$\bullet$ & $\infty$ & $V$ & $\stackrel{\Delta}{N}$ & $\stackrel{\sim}{ }$ & $\triangle$ & o \\
\hline$\triangle$ & $\stackrel{\dot{\varphi}}{\mapsto}$ & $\omega$ & के & 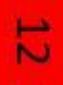 & $\omega$ & 宊 \\
\hline$\triangle$ & $\mapsto$ & $V$ & 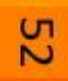 & $\vec{N}$ & $\omega$ & $\infty$ \\
\hline$\mapsto$ & '́ & $V$ & g) & $\mapsto$ & $\omega$ & $V$ \\
\hline$\infty$ & $\infty$ & v & $\exists$ & $\stackrel{\leftrightarrow}{\sim}$ & $\Delta$ & $\infty$ \\
\hline
\end{tabular}

Figure 1

Heat Map of Cases and Controls with $5+$ year follow up 